NBER WORKING PAPERS SERIES

\title{
OPENNESS AND INFLATION: THEORY AND EVIDENCE
}

\author{
David Romer
}

Working Paper No. 3936

\author{
NATIONAL BUREAU OF ECONOMIC RESEARCH \\ 1050 Massachusetts Avenue \\ Cambridge, MA 02138 \\ December 1991
}

I thank David Parsley and Brian A'Hearn for research assistance, Laurence Ball, Kenneth Rogoff, Christina Romer, and seminar participants at the Federal Reserve Board, Stanford University, the University of California, Berkeley, and the University of Texas for helpful comments, and the National science Foundation for financial support. This paper is part of NBER's research programs in Monetary Economics and Economic Fluctuations. Any opinions expressed are those of the author and not those of the National Bureau of Economic Research. 
NBER Working Paper $\$ 3936$

December 1991

OPENNESS AND INFLATION: THEORY AND EVIDENCE

\section{ABSTRACT}

This paper points out and tests a straight forward but previously unnoticed prediction of models in which the absence of precommitment in monetary policy leads to excessive inflation. Because unanticipated monetary expansion leads to real exchange rate depreciation, and because the harms of real depreciation are greater in more open economies, the benefits of surprise expansion are decreasing in the degree of openness. Thus, under discretionary policy-making, money growth and inflation will be lower in more open economies. After presenting a simple theoretical model demonstrating this prediction of the theory, the paper examines the link between openness and inflation using cross-country data. The data reveal a strong negative link between openness and inflation.

David Romer Department of Economics University of California Berkeley, CA 94720 and NBER 


\section{INTRODUCTION}

In their classic paper, Kydland and Prescott (1977) demonstrate that the absence of precommitment in monetary policy can lead to inefficiently high levels of inflation. When imperfect competition or a distortionary tax system causes the natural level of output to be suboptimal and when monetary policy can affect real output, policy-makers have an incentive to attempt to create surprise inflation. But pollcy cannot on average be more expansionary than price and wage setters expect. As a result, in a one-time game without binding precomnitment the equilibrium rate of inflation is inefficiently high and output remains at its natural rate.

Kydland and Prescott's paper has given rise to a vast theoretical literature. The analysis of macroeconomic policy-making without precommitment has been extended to multiple periods, stochastic environments, asymmetric information, multiple policy-makers, multiple countries, and so on. ${ }^{2}$ Yet, almost fifteen years after Kydland and Prescott's paper, there is virtually no empirical evidence on the question of whether the mechanism identified by Kydland and Prescott is important to actual inflations. ${ }^{2}$ One view, advocated

1 For surveys, see Rogoff (1989) and Fischer (1990). An important earlier paper is Phelps (1967).

2 An important exception is the work of Alesina and others on "rational partisan business cycles" (see, for example, Alesina, 1988). The results of this work have been largely supportive of the predictions of a Kydlandprescott-style model extended to the case of multiple policy-makers (but see Sheffrin, 1988). 
for example by Barro and Gordon (1983a), is that Kydland and Prescott's model is a valuable model of actual monetary policies and that it gives significant insights into a broad range of phenomena. The other extreme, argued by Taylor (1983), is that there are institutions or mechanisms that largely eliminate policy-makers' tendency to attempt systematically to cause surprise inflation. Governments appear to be able to largely overcome the dynamic inconsistency problem in other contexts; for example, it would not be correct to deduce from the observation that governments generally do not make enforceable promises concerning future tax rates on capital that in seeking to understand actual capital taxation policies we should focus on the dynamically consistent equilibria of one-time games. In the case of monetary policy, reputational mechanisms (Barro and Gordon, 1983b) or the appointment of "conservative" policy-makers (Rogoff, 1985a) could overcome the tendency toward inefficiently high rates of inflation.

The purpose of this paper is to demonstrate a prediction of models in which the absence of precommitment in monetary policy leads to inefficiently high inflation, and then to test that prediction. The source of the prediction is straightforward. In his extension of the basic models of dynamic consistency and monetary policy to open-economy settings, Rogoff (1985b) notes that surprise monetary expansion causes the real exchange rate to depreciate, and that this reduces the incentives to undertake expansion. This observation is the source of Rogoff's result that international policy coordination can be undesirable in the absence of precommitment: because coordinated expansion by two countries cannot cause each country's currency to depreciate against the other's, the incentive to expand -- and thus equilibrium inflation - - is higher under coordination. To put it differently, by coordinating their monetary policies, two countries in effect turn 
themselves into a single larger, and hence less open, economy; this decreased openness reduces the harm of the real depreciation induced by surprise monetary expansion, and thus raises equilibrium inflation. The same reasoning leads directly to the prediction that I focus on in this paper: the more open an economy is, the smaller is the incentive to expand, and so the lower is the equilibrium rate of inflation. Thus models of inefficiently high inflation arising from the absence of precommitment predict an inverse relationship between openness and inflation.

The core of theoretical models of monetary policy without precommitment involves policy-makers' incentives to Inflate. By testing a prediction of the models concerning a determinant of the level of inflation, I am thus testing the central element of these models. Indeed, an important source of the appeal of these models is that they provide a candidate explanation of modern economies" tendency toward what many perceive to be "excessive" inflation.

The remainder of the paper consists of three sections. Section II presents a simple model that illustrates the basic prediction that I seek to test. Section III presents the empirical evidence concerning the relation between openness and inflation. I find that there is a quantitatively large, statistically significant, and robust negative relationship between openness and inflation, confirming the prediction of the theory. I consider several alternative explanations of the relationship, but find that none appear to $f i t$ the facts. I also find that the link between openness and inflation is absent in the most highly developed countries; In these countries average inflation rates are low and are unrelated to openness. The results thus suggest that only a small group of developed countries have overcome the dynamic inconsistency of optimal monetary policy. Section IV concludes. 


\section{AN ILLUSTRATIVE MODEL}

In this section I present a simple theoretical model that demonstrates that the benefits of a surprise monetary expansion are smaller in more open economies, and hence that models of discretionary monetary policy predict that inflation is higher in less open economies. The model is a straightforward extension to an open economy setting of existing models of the macroeconomics of imperfect competition with sticky prices (for example, Blanchard and Kiyotaki, 1987, and Ball and Romer, 1990). Other models in the same spirit, such as the one that Rogoff uses to show that international policy coordination can be harmful, would yield the same prediction.

Assumptions. Consider a country whose citizens consume a continuum of differentiated goods and that imports fraction a of those goods. a thus measures the country's degree of openness. Let $e$ be the change from the preceding period in the $\log$ exchange rate, $p^{*}$ the change in the log price index for foreign goods in foreign currency units, and $p$ the change in the $\log$ price index for domestically-produced goods in domestic currency units. Then the rate of consumer price inflation (that is, the change in the log (PI), $x$, is given by

$$
x-a\left(e+p^{*}\right)+(1-a) p .
$$

Assume that an individual's utility from consumption is a CES combination of his or her consumptions of the different goods, and let $a<1$ denote the inverse of the elasticity of substitution between any two goods. Because goods produced at home are imperfect substitutes for goods produced abroad, an expansion of domestic output must drive down the relative price of 
domestically produced goods:

$$
e+p^{\star}-p=\alpha\left(y-y^{\star}\right)
$$

where $y$ is the change in $\log$ domestic output and $y^{*}$ the change in $\log$ forelgn output.

Assume that fraction $f$ of domestic prices are flexible in the short run and the remaining 1 -f are rigid. (This could arise from overlapping contracts or heterogeneous costs of price adjustment, for example. I discuss below how $f$ could be made endogenous.) Then

$$
p-f \overline{\mathbf{p}}+(1-f) \overline{\mathbf{p}}
$$

where $\bar{p}$ and $\bar{p}$ are the rates of inflation of prices that are flexible in the short run and those that are fixed, respectively.

I assume that flexible prices are set according to

$$
\mathbf{P}-\mathrm{X}-\phi \mathrm{Y}, \quad \phi>0 \text {, }
$$

where upper case symbols denote log levels (rather than log changes) of the corresponding lower case variables. Equation (4) states that the real prices charged by firms that can adjust their prices ex post are increasing in aggregate output. $\phi$ measures the degree of responsiveness of the flexible prices to output. For example, in the simple case in which labor is the only input into production, the labor market is competitive, wages are flexible, and there are constant returns, $\phi$ would be simply the inverse of the elasticity of labor supply. Since, as will be seen below, initially prices are at their equilibrium values, equation (4) also holds in changes:

$$
\tilde{\mathrm{p}}-\mathrm{x}-\phi \mathrm{y} \text {. }
$$


Finally, money demand is given by

$$
m-p-y \text {. }
$$

where $m$ is the change in the $\log$ money stock. (5) could arise from a cashin-advance constraint or from an assumption that money enters the utility function; alternatively, it can be viewed simply as a short-cut way of modeling aggregate demand.

I assume that analogous equations describe the rest of the world, which for simplicity I assume consists of a single country. Thus, letting a ' ' denote a foreign variable:

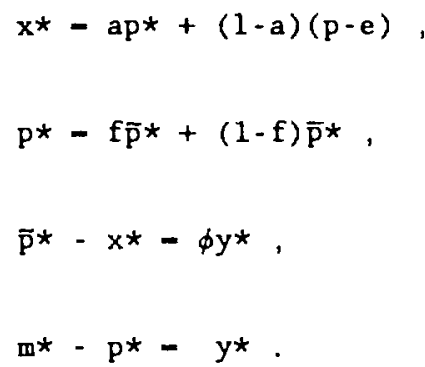

If all prices were perfectly flexible $(f-1)$, the equilibrium would be $p-m, \dot{p} *-m *, y=y^{*}-0$, and $e=m-m *$. Because of imperfect competition, the equilibrium level of output is less than the socially optimal level. Assuming that each good is produced by a separate firm, each firm's ratio of price to marginal cost is $1 /(1-\alpha)$. Thus, at the flexible-price equilibrium, the marginal impact of an increase in $y$ on welfare (with the real exchange rate held fixed), measured in units of real output, is $\alpha$. In addition, changes in the real exchange rate, because they represent changes in the real price of foreign goods, also affect welfare. Since the equilibrium level of output is one and since the fraction of goods purchased from abroad is $a$, the marginal welfare impact of a rise in $e+p^{*}-p$ (with $y$ unchanged) 
is $-a$.

Finally, following the standard practice in this literature, I assume a direct cost to inflation. Because it seems realistic, I assume that it is CPI inflation, rather than domestic price inflation, that is costly. Assuming that the cost of inflation is associated with domestic inflation would not change the central results of the model. I write the cost as $c(x)$ and assume $c^{\prime}(\cdot)>0, \quad c^{\prime \prime}(\cdot)>0$.

The effects of a monetary expansion. Equations (1)-(9) can be used to find the effects of an ex post monetary expansion - that is, an increase in the money supply $m$ with predetermined prices, $\bar{p}$ (and $\bar{p} \star$ ) already set. The effects on output, domestic inflation, CPI inflation, and the real exchange rate are given by:
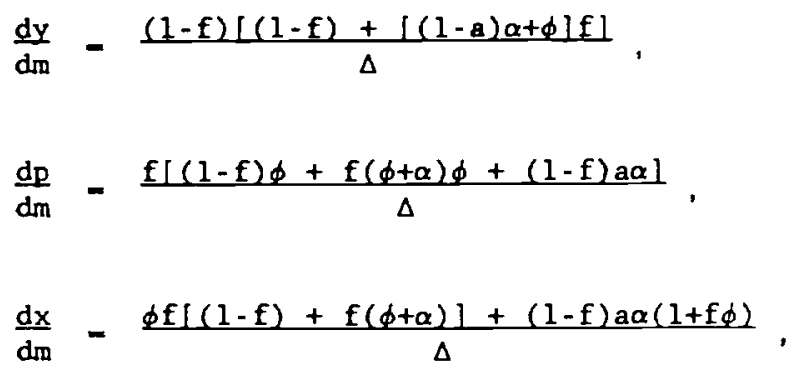

where

$$
\Delta=[(1-f)+\phi f][(1-f)+(\phi+\alpha) f] .
$$

Since $\Delta$ does not depend on the degree of openness a, it follows immediately from $(10 a)-(10 c)$ that the effect of a monetary expansion on output is smaller in a more open economy, and that its effects on both domestic and 
CPI Inflation are larger. Thus the output-inflation tradeoff facing policymakers (measured as either $d y / d p$ or $d y / d x$ ) is less favorable in a more open economy. The impact of an increase in money growth on the real exchange rate, in contrast, is independent of openness. But since the welfare cost of a given real exchange rate depreciation is larger the more open the economy - since a larger fraction of goods are purchased from abroad - real exchange rate depreciation provides a greater disincentive to expansionary monetary policy in more open economies.

The intuition for these results is straightforward. A monetary expansion with sticky prices raises output at home relative to output abroad. Inducing consumers to buy more domestic goods relative to foreign goods requires that the relative price of domestic goods fall - that is, that there be real depreciation. ${ }^{3}$ This depreciation affects inflation through two channels. First, foreign goods prices are a component of the CPI, and so depreciation directly increases CPI inflation. Second, depreciation raises the costs of domestic firms. For example, if nominal wages are at all flexible, the rise in the CPI causes wages to increase. Thus flexible-price firms raise their prices by more than they would without the depreciation, again Increasing inflation.

The more open the economy, the larger is the weight of foreign goods in the CPI. Thus the impact of the monetary expansion on both CPI inflation and domestic price inflation is larger in a more open economy. As a result, more of the monetary expansion is translated into higher prices, and less into

3 Note that, as long as domestically-produced goods consumed at home and imports are imperfect substitutes, real depreciation is necessary even if the country faces a perfectly elastic demand curve for its export goods. Thus the central results of the model would also hold in a model of an economy that produced services and protected manufactures for domestic consumption and primary commodities for export. 
higher output.

In addition, the more open the economy, the smaller is the impact of the monetary expansion on foreign output. The reasoning parallels the analysis above: when a is large, the home economy is small relative to the foreign economy, and so the real appreciation for the foreign country has litele Impact of foreign firms' prices, and hence little impact on foreign output. Thus increased openness reduces the impact of a monetary expansion on both home and foreign output. With the specific assumptions I have made, the net effect is that the impact on the real exchange rate is independent of the degree of openness. But, because forelgn goods represent a larger share of consumption in a more open economy, both the direct welfare cost of the real depreciation and its impact on inflation (measured using either the CPI or domestic prices) are greater in a more open economy.

Equilibrium inflation. To complete the model it is necessary to specify how $\bar{p}, \bar{p}^{\star}, \mathbb{m}$, and $m^{\star}$ are determined. I assume that firms that set prices before $m$ is known have the same objective function as firms that set prices ex post. Thus, paralleling $\left(4^{\prime}\right)$ and ( 8 ),

$$
\bar{p}=E[x+\phi y]
$$$$
\bar{p}^{\star}-E\left[x^{\star}+\phi y^{\star}\right],
$$

where $E$ denotes expectations conditional on the information available when prices are set. Together with equations (1) - (9), (12) and (13) imply

$$
\begin{aligned}
& \bar{p}-E[m], \\
& \bar{p} \star-E\left[m^{\star}\right] .
\end{aligned}
$$

There are two requirements for equilibrium. The first is that 
expectations are rational. Since there is no uncertainty in the model, from (14) and (15) this condition is simply $\overline{\mathrm{p}}-\mathrm{m}, \overline{\mathrm{p}} \star-\mathrm{m}^{\star}$. Thus in equilibrium output equals its flexible-price level.

The second equilibrium condition is that the monetary authority chooses money growth optimally ex post, taking $\overline{\mathrm{p}}$ (and $\overline{\mathrm{p}}^{\star}$ ) as given. This requires

$$
\alpha \frac{d y}{d m}-a \frac{d(e+p t-p)}{d m}-c^{\prime}(x) \frac{d x}{d m} \text {. }
$$

Together, (14) and (16) imply that in equilibrium (16) must hold at a point at which $\bar{p}-m$, and hence $y=0$ - that is, at the flexible-price equilibrium. That is, expected inflation, and hence the growth rate of prices that are set in advance, must adjust to the point where the monetary authority does not wish to create additional inflation ex post. Similarly, the condition for the equilibrium rate of money growth in the foreign country is

$$
\alpha \frac{d y^{\star}}{d m^{\star}}+(1-a) \frac{d\left(e+p^{\star}-p\right)}{d m^{*}}-c^{\prime}\left(x^{\star}\right) \frac{d x^{*}}{d m^{*}} \text {. }
$$

(15) implies that this condition must hold at a point where $\bar{p}^{\star}-m^{*}$.

Substituting (10a), (10c), and (10d) into (16) establishes formally the model's central prediction that increased openness reduces equilibrium inflation. dy/dm is decreasing in $a$, and $a[d(e+p *-p) / d m]$ is increasing in a. Thus the left-hand side of (16) is decreasing in a. In addition, $\mathrm{dx} / \mathrm{dm}$ is increasing in $\mathrm{a}^{\text {. Since }} \mathrm{c}^{\prime}(\mathrm{x})$ and $\mathrm{c}^{\prime \prime}(\mathrm{x})$ are positive, maintaining the equality as a rises requires that $x$ fall."

"Allowing the fraction of firms with flexible prices ( $f$ ), to be endogenous would strengthen these results. Suppose that it is costly for a firm to retain the ability to adjust its price ex post, and suppose that this cost varies across firms. One can show that in response to a given surprise change either in $m$ or in $m *$, a firm's desired price change is larger the more open the economy (that is, $d \tilde{p} / d m$ and $d \tilde{p} / d m \star$ are increasing in $a$ ). The firm's incentive to adjust its price is therefore greater in a more open 
Because the basic mechanism through which increased openness reduces equilibrium inflation is straightforward, the central results of the model -. that increased openness worsens the output-inflation tradeoff and lowers equilibrium inflation -- are quite robust. For example, assuning that foreign output and prices are unaffected by domestic monetary expansion does not change these conclusions. The same is true of allowing the effect of domestic output relative to foreign output on the real exchange rate and the welfare benefit of increased output - - both of which are currently determined by $\alpha$, the inverse of the elasticity of substitution between goods - to be governed by separate parameters. Similarly, the choices of whether it is CPI inflation or domestic price inflation that is relevant for firms' price setting decisions, for money demand, and for the costs of inflation are not important to the model's conclusions.

economy. Under natural assumptions - - for example, that the distribution of costs of having a flexible price is the same in the two countries and that the variances of the surprise monetary shocks in the two countries are equal - the fraction of firms with flexible prices will therefore be larger in the more open economy. This would provide another channel through which increased openness worsened the output-inflation tradeoff, and would therefore cause increased openness to lower equilibrium inflation even further. 


\section{THE EVIDENCE}

In this section I use cross-country data to test the prediction of the theory that inflation will be higher in less open economies.

Sample and Data. I focus on the modern exchange rate system that began in 1973. Because the Bretton woods system that existed before 1973 limited countries' ability to pursue independent monetary policies, the post-1973 regime appears to provide a better setting for testing the theory.

I begin with as broad a sample of countries as possible. There is no a priori reason to expect the predictions of the theory to apply only to certain types of countries. ${ }^{5}$ And the basic variables that the theory focuses on -inflation and the import share - can be measured, at least approximately, with relative ease. My basic sample therefore consists of all of the noncentrally planned economies listed by Summers and Heston (1988) for whom data on openness and inflation are available. This sample consists of 114 countries. ${ }^{6}$ I also investigate the relationship between openness and inflation for a variety of narrower samples.

5 In particular, the fact that many developing countries are on fixed exchange rates does not provide a reason to exclude these countries from the sample. For a worldwide fixed exchange rate regime like the Bretton Woods system, one can make a case that it could serve to coordinate or preconmit policy. But it is difficult to see how just a stated policy by a country that it plans to hold its exchange rate fixed can serve as a precommitment or coordination device; certainly many countries with "fixed" exchange rates change their exchange rates ex post.

6 Seven non-centrally planned economies listed by Summers and Heston are excluded from the sample because of insufficient data. They are Afghanistan, Angola, Chad, Guinea, Iraq, Mali, and Mozambique. 
National accounts data are from the International Financial statistics of the International Monetary Fund.' Inflation is measured as the change in the $\log$ GDP or GNP deflator. For countries for which this serfes is not avallable, I use the change in the log CPI instead (this series is from IMF, 1986a). Openness is measured as the average share of imports in GDP or GNP over the years beginning in 1973. Again, the standard IFS series is unavallable for a few countries; for these countries I use an alternative series also constructed by the IMF (IMF, 1988). Although the two measures of imports are slightly differently conceptually (see IMF, 1988, pp. v-vi11). when both measures are avallable they are similar. Finally, data on real income per capita - - which is used as a control variable in some specifications - - are from Summers and Heston; I use the figure for 1980 , since this is approximately the mid-point of the post-1973 period and since 1980 is a benchmark year for Summers and Heston. Table Al at the end of the paper presents the basic data used in the tests.

Specification. A few countries in the sample have extremely high average Inflation rates. Thus the parameter estimates from a linear regression would be determined almost entirely by a handful of observations. A simple change that reduces the importance of the countries with extreme inflation rates is to consider the $\log$ rather than the level of average inflation. Thus my basic specification is a regression of the log of average

7 The IMF does not provide data for Taiwan. These data (which are comparable to the standard IFS data) are therefore taken from the Statistical Yearbook of the Republic of China. 
inflation on a constant and the degree of openness. ${ }^{8}$

My other specifications differ from the basic one by controlling for other factors. I consider three types of control variables. The first is real income per capita; this can serve as a general measure of development, and thus may capture a variety of factors that influence average inflation. The second is a set of dummy variables for OECD membership and for various regions; these too are likely to be correlated with factors that influence average inflation. The third are dumny varlables for the use of the CPI rather than the GDP deflator to measure inflation and for the alternative measure of openness; these capture any differences in the average levels of the alternative measures. Note that the exclusion of any factor that could potentially affect average inflation biases the coefficient on openness only if the omitted factor is correlated with openness. Thus, since there is no reason to expect such potential determinants of the average inflation rate as political stability, the independence of the central bank, and so on to be correlated with openness, the exclusion of variables capturing these additional influences on inflation is unlikely to cause bias.9

Basic results. Figure 1 and Table 1 present the results for the broad sample of countries.

a Considering log inflation would not be appropriate if some countries had very low average rates of inflation, since the logarithmic transformation would give those countries undue weight in the regressions. No countries in the sample have extremely low inflation rates, however; the lowest average rate (Singapore's) is 3.68 .

9 The alternative strategy of attempting to add measures of as many political and economic determinants of the average inflation rate as possible to the regression would result in a drastic reduction in the sample size. Cukierman, Edwards, and Tabellini (1989) investigate the link between political stability and inflation. 
Figure 1 is a scatterplot of the mean rate of inflation since 1973 (measured on a logarithmic scale) against the degree of openness. The figure shows a negative relationship between openness and inflation. The corresponding regression is reported in the first column of Table 1 . The $t$ statistic on openness is -3.8 : there is a statistically significant negative relationship between openness and inflation, just as the theory predicts. Moreover, the estimated impact of openness on inflation is quantitatively large. The point estimates in Column 1, for example, imply an average rate of inflation of 18 for a closed economy, 148 for an economy with an import share of 258, 118 for an import share of 508, and 88 for an import share of 758 . Finally, the fraction of the variation in inflation explained by the regression is non-trivial: openness alone accounts for over ten percent of the cross-country variation in average inflation rates. ${ }^{10}$

The remaining columns of Table 1 investigate the robustness of this result to some simple changes in specification. In Column 2 I add dummy variables for the use of the CPI to measure inflation and for the alternative measure of the import share. This change alters the results only trivially. In column 3 I also add log real income per capita to the regression. The regression suggests that higher real income is associated with a modest decline in average inflation. The estimated impact of openness on inflation

10 As Figure 1 shows, two countries in the sample - S Singapore and Lesotho - have average ratios of imports to GDP in excess of 1008 . In the case of Singapore, this simply reflects the facts that imports and exports are measured in terms of gross value and GDP in terms of value-added, and that value-added in Singapore is low relative to the gross value of imports. In the case of Lesotho, the ratio in excess of 100 arises from the use of GDP rather than GNP as the measure of output and the importance of labor income earned abroad to that economy. Thus ratios of imports to GDP over 100 do not indicate data errors. Nonetheless, one might be concerned that these few extreme observations had an excessive influence on the results. Reestimating the regressions with Singapore and Lesotho excluded, however, lowers the $t$ statistic on openness only modestly. 


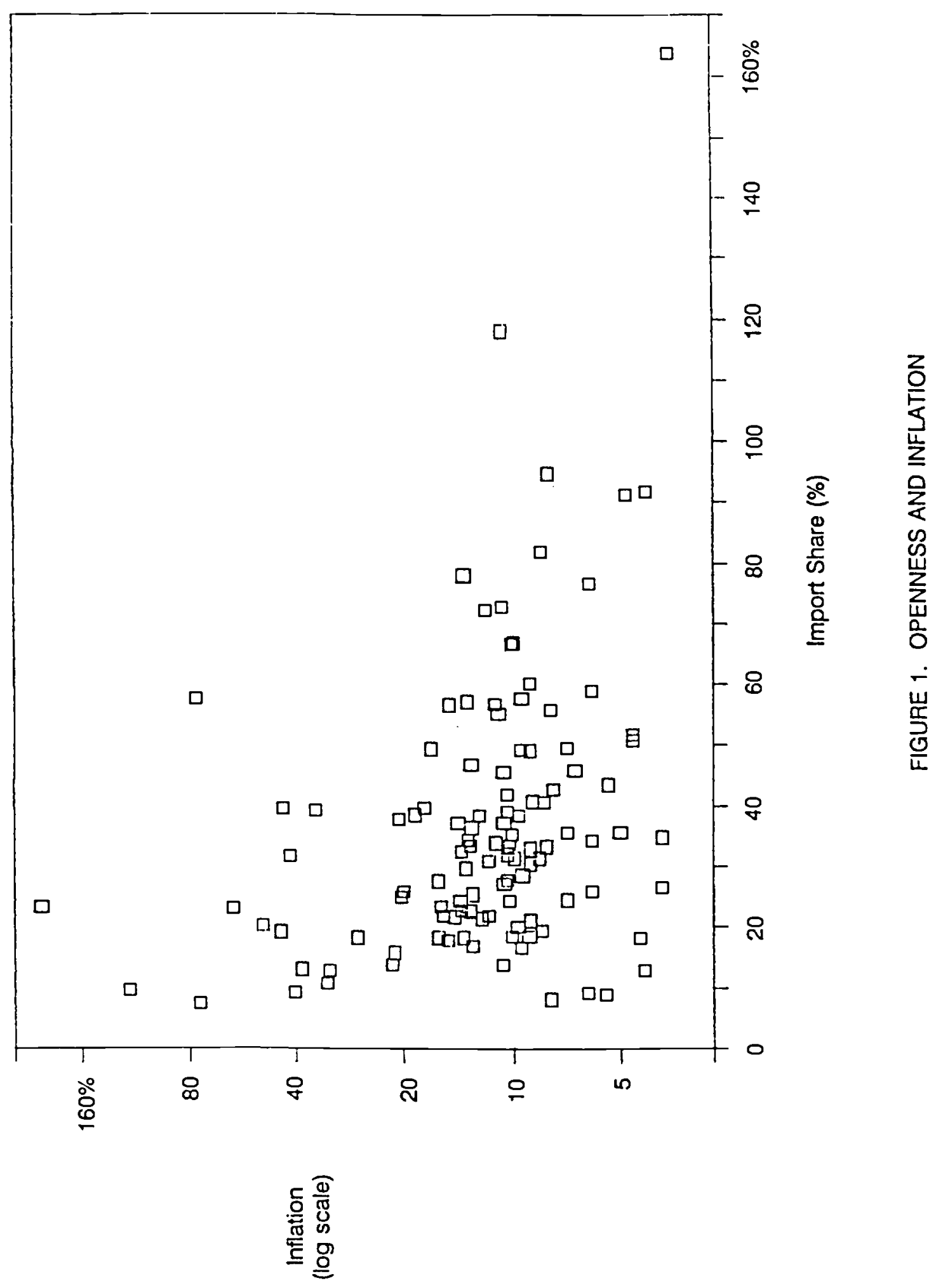


TABLE 1

RESULTS FOR THE FULL SAMPLE

\begin{tabular}{|c|c|c|c|c|}
\hline & (1) & (2) & (3) & (4) \\
\hline \multirow[t]{2}{*}{ Constant } & -1.730 & -1.740 & -1.375 & -1.919 \\
\hline & $(0.117)$ & $(0.118)$ & $(0.471)$ & $(0.718)$ \\
\hline \multirow[t]{2}{*}{ Openness } & -1.006 & -1.070 & -1.019 & -0.827 \\
\hline & $(0.266)$ & $(0.272)$ & $(0.280)$ & $(0.266)$ \\
\hline Log Real Income & & & -0.049 & -0.014 \\
\hline per Capita & & & $(0.061)$ & $(0.099)$ \\
\hline Data Dummies Included? & No & Yes & Yes & Yes \\
\hline Regional Dummies Included? & No & No & No & Yes \\
\hline $\mathrm{R}^{2}$ & .114 & .124 & .129 & .373 \\
\hline S.E.E. & .671 & .673 & .674 & .585 \\
\hline
\end{tabular}

Standard errors are in parentheses. The dependent variable is the log of the average inflation rate since 1973. "Data dummies" are dummy variables for the alternative measures of openness and inflation (described in the text). "Regional dummies" are dummy variables for South Amcrica, Central America, Africa, OECD membership, and the major oil producers. 
is again little changed. 11

Column 4 reports the results of including dumnies for OECD membership, the major oil producers, South America, Central America (including the Caribbean), and Africa. The coefficients on the dummies (which are not reported in the table) confirm that there are differences in inflation rates across regions. The dummy for South American countries is large (1.17) and highly significant; those for Africa and Central America are of moderate size (.20 and .30, respectively); and those for OECD membership and the oil producers are small (.09 and .06). The null hypothesis that the coefficients on the dumies are all zero is strongly rejected. The estimated link between openness and inflation, however, is little changed: the coefficient is about eighty percent of its previous value, and the $t$-statistic remains greater than 3.

Robustness across samples. Table 2 investigates the results for a variety of sub-samples. For each sample I report the results only for the specification that includes $\log$ real income per capita and the dumny variables for the use of alternative data sources. Exclusion of these control variables or inclusion of the regional durmies has little effect on the results.

Column 1 excludes countries with average inflation rates greater than 308 from the sample. The estimated coefficient on openness is smaller than before, but the t-statistic remains in excess of 3 . Thus the results do not depend on a few countries with extreme inflation rates.

Column 2 eliminates several types of countries whose monetary policies are closely tied to those of other countries, and to whom the model thus does

11 Because real income is an extremely poor index of development for the major oil producing countries, all regressions that include real income are also estimated with the oil producers excluded from the sample. This change has no important effect on the results. 


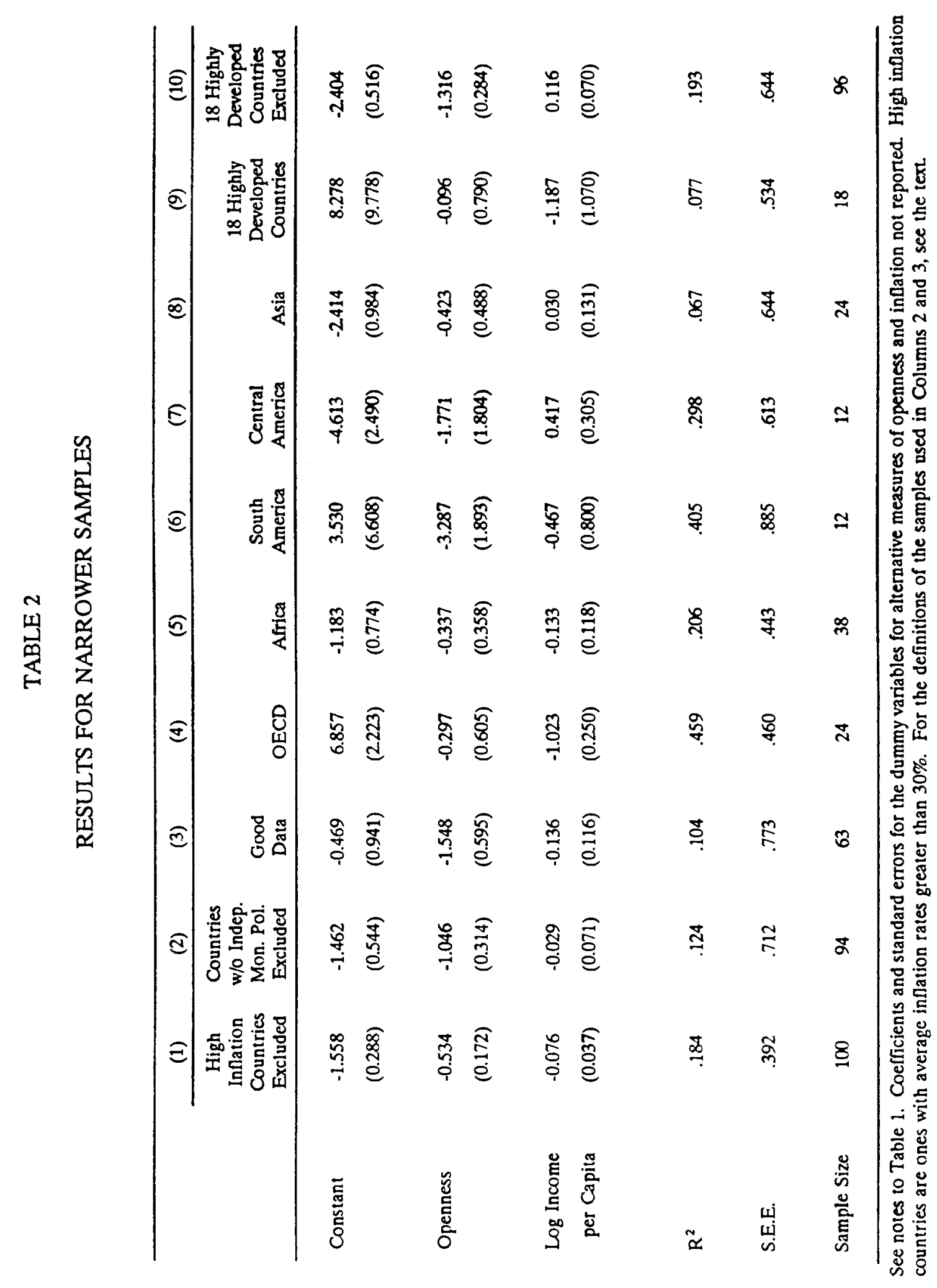


not clearly apply. Specifically, I exclude the members of the two Francophone African monetary unions, the members of the European Monetary System, and two countries (Liberia and Panama) that employ U.S. dollars rather than domestic currencies. This change has virtually no effect on the coefficient on openness, although the standard error does increase slightly.

Column 3 restricts the sample to countries for whom reliable data are avallable - specifically, countries whose national accounts data receive a rating of " $C$ " or better from Summers and Heston, for whom the alternative measures of inflation and the import share did not have to be used, and who are not major oil producers. This sample consists of 63 countries. The point estimates imply a larger impact of openness on inflation than does the corresponding regression for the full sample (Column 3 of Table 1). The $t$ statistic on openness, however, is somewhat smaller.

Columns 4 through 8 of the table examine the relationship between openness and inflation within regions (again considering the OECD as a "region"). For each region, the point estimates offer support for the predicted negative relationship. There is also no evidence that the relationship differs across regions; the null hypothesis that the coefficients on openness are equal for all regions cannot be rejected. Given the small sample sizes, however, the coefficients for the regional sub-samples are generally insignificant.

The robustness of the result is not surprising. The 15 most open economies in the sample all have average inflation rates of less than 148 , and 13 have rates less than or equal to the sample median of 118 . At the other extreme, the 10 most closed economies include 6 of the 14 countries with average inflation rates over 308 . It is difficult to see what characteristic differentiates such low inflation countries as Bahrain, Barbados, Guyana, 
Malaysia, Malta, Mauritania, the Netherlands, Papua New Guinea, Singapore, Surinam, and Tunisia from such high inflation countries as Argentina, Brazil. Ghana, Indonesia, Iran, Mexico, Nigeria, Peru, Sudan, Turkey, and Uganda other than the fact that the former are quite open and the latter relatively closed.

Although the results are generally robust across subsamples, there is no evidence that the prediction of the theory holds for the most highly developed countries. Consider for example the 18 wealthiest countries in the sample other than the major oil producers. ${ }^{12}$ Among these countries, there is virtually no link between openness and inflation, although a two standard error confidence interval also includes large negative values (Column 9 of Table 2). More important, average inflation rates in these countries are low. The average for the 18 is 8.78 , and the regression equation for the full sample, even controlling for per capita income (Column 3 of Table 1), underpredicts inflation for 17 of the 18 .

Outside this small group of highly developed countries, in contrast, average inflation rates are high and are strongly related to openness. The average inflation rate for the set of 96 countries that excludes the highly developed 18 is 18.98 . In this sample, controlling for per capita income, the t-statistic on openness is -4.6 , and the point estimates imply that for a country with per capita income equal to the sample median, average inflation falls from 218 to 88 as openness rises from 0 to 758 (Column 10 of Table 2). Finally, openness accounts for a substantial fraction of the variation in inflation among these countries: a simple regression of the log of average

12 The countries (listed in order of 1980 per capita income) are the United States, Canada, Norway, Luxembourg, Switzerland, Germany, France, Denmark, Japan, Iceland, Belgium, the Netherlands, Sweden, Finland, Australia, Austria, the United Kingdom, and New Zealand. For comparison, the next wealthiest countries (again excluding major oil producers) are Hong Kong, Italy, Trinidad and Tobago, Israel, Spain, Singapore, Ireland, Malta, Uruguay. and Barbados. 
inflation on a constant and openness has an $R^{2}$ of .17 .

Thus the data are consistent with the view that there is a group of approximately 15 to $20 \mathrm{highly}$ developed countries that have found some means of solving the problem of dynamic inconsistency of optimal monetary policy. For these countries, average rates of inflation are low and are unrelated to a measure of policy-makers' incentives to attempt surprise monetary expansions. In the rest of the world, on the other hand, the problem of dynamic inconsistency does not appear to have been solved: average rates of inflation are much higher and are strongly related to the benefits of expansion. ${ }^{13}$

Alternative Explanations. The natural interpretation of the negative association between openness and average inflation is that greater openness reduces policy-makers' incentives to undertake surprise monetary expansions, and thus results in lower inflation. In this section I consider two alternative explanations of this link.

The first possibility is that openness is endogenous. The ratio of imports to GDP depends not just on a country's size - - the variable emphasized in the theoretical model - - but also on the country's policy choices. It is possible, for example, that countries that adopt protectionist policies also adopt other policies benefiting special interest groups, and that this in turn leads to large budget deficits and hence to high rates of inflation to

13 For the sample that excludes the 18 highly developed countries, there is no evidence either than average rates of inflation are declining in income or that the link between openness and inflation weakens as income rises. In this group of countries, average inflation is in fact increasing in average income (Column 10 of Table 2). And when an interaction term between openness and $\log$ real income is added to the regression, its coefficient is negative and significant, suggesting that the inverse link between openness and inflation becomes stronger rather than weaker as income rises. Thus the data are not at all supportive of the view that the extent to which countries have solved the dynamic inconsistency problem is a smoothly increasing function of their level of development. 
generate seignorage revenues. If so, a negative correlation between openness and inflation could arise through this channel rather than through the impact of openness on policy-makers' incentives to pursue expansionary policies.

To address this possibility, I reestimate the basic regressions by instrumental variables, treating openness as endogenous and using a country's land area (in logarithms) as an instrument. Data on land area are listed in the final column of Table Al. A country's land area is not determined by its current policies. Thus land area can reasonably be assumed to be uncorrelated with the policy determinants of the ratio of imports to GDP. At the same time, land area is strongly negatively correlated with openness. A regression of the ratio of imports to GDP on a constant and $\log$ land area produces a $t$ statistic on $\log$ land area of -9.5 and an $R^{2}$ of 0.45 .

Table 3 reports the instrumental variables estimates. The IV estimates of the impact of openness on inflation are in fact larger than the OLS estimates. In the simple regression of the $\log$ of average inflation on openness and a constant, for example, the IV estimate is -1.32 while the OLS estimate is -1.01 . In addition, the IV estimates are always highly significant. Hausman tests fail to reject the null hypothesis that the IV and OLS estimates are equal. Thus there is no evidence that possible endogeneity of the import share is the source of the negative association between the import share and average inflation.

The second alternative explanation that I consider is that the negative association between openness and inflation reflects considerations involving the government budget and seignorage rather than the absence of precomnitment in monetary policy. The argument takes two specific forms. First, the amount of revenue generated by a given tariff is increasing in the openness of the economy. Thus the governments of smaller countries may obtain larger 
TABLE 3

INSTRUMENTAL VARIABLES ESTIMATES

\begin{tabular}{|c|c|c|c|c|}
\hline & (1) & (2) & (3) & (4) \\
\hline \multirow[t]{2}{*}{ Constant } & -1.615 & -1.628 & -1.388 & -2.020 \\
\hline & $(0.161)$ & $(0.159)$ & $(0.474)$ & $(0.746)$ \\
\hline \multirow[t]{2}{*}{ Openness } & -1.316 & -1.395 & -1.345 & -0.994 \\
\hline & $(0.399)$ & $(0.410)$ & $(0.433)$ & $(0.422)$ \\
\hline Log Real Income & & & -0.033 & -0.010 \\
\hline per Capita & & & $(0.063)$ & $(0.109)$ \\
\hline Data Dummies Included? & No & Yes & Yes & Yes \\
\hline Regional Dummies Included? & No & No & No & Yes \\
\hline$R^{2}$ & .103 & .112 & .118 & .371 \\
\hline S.E.E. & .675 & .677 & .678 & .586 \\
\hline
\end{tabular}

See notes to Table 1. The equations are estimated by instrumental variables, treating openness as endogenous and using log land area (along with the other right-hand side variables) as an instrument. 
fractions of their revenues from tariffs, and may therefore rely less on other sources of revenue, including seignorage. The result may be lower rates of inflation. ${ }^{14}$ Second, the elasticity of demand for domestic currency with respect to the inflation rate may be higher in more open economies: greater trade may make foreign currencies more easily available, and may therefore make it easier for residents to obtain substitutes for domestic currency. If this is the case, then the optimal tax rate on domestic currency - the inflation rate - is lower in more open economies.

Although these budgetary arguments are not a priori implausible, three pieces of evidence strongly suggest that they do not account for the negative association between openness and inflation. First, tariffs and seignorage are much more important sources of revenue for poor countries than for rich ones. The average share of central government revenue in 1980 obtained from tariffs is 38 for the 18 highly developed countries, 11 for countries with per capita incomes between $\$ 4000$ and $\$ 7300,26 z$ for countries with per capita incomes between $\$ 1000$ and $\$ 4000$, and 32 for countries with per capita incomes below \$1000. Similarly, the average shares of revenue coming from seignorage for these four groups of countries are $0 \%, 28,68$, and 88 , respectively. (IMF, 1986b, pp. 8-9, 24-25.) $)^{15}$ Since the budgetary arguments rest on the importance of these revenue sources, they predict that the link between openness and inflation will decline as per capita income rises. This prediction can be tested by adding an interaction term between openness and log real income per capita to the regressions. If the link between openness

14 This argument is made by Cukierman, Edwards, and Tabellini (1989)

15 Since per capita income is a very poor measure of development for the major oil producers, these countries are excluded from the calculations. Including them in either the $\$ 4000-\$ 7300$ or the $\$ 1000-4000$ group has little effect. 
and average inflation lessens as tariffs and seignorage decline in importance, the coefficient on the interaction term will be positive.

There is no evidence that the relationship between openness and inflation becomes weaker as income rises. Despite the fact that the opennessinflation link is absent among the most highly developed countries, for the full sample the interaction term enters with a negative coefficient, contrary to the prediction of the budgetary explanation of the results. In the regression analogous to Column 3 of Table 1, for example, the coefficient on the interaction variable is -0.37 (with a standard error of 0.28 ). The point estimates imply an effect of openness on $\log$ inflation that increases from -0.55 to -1.33 as 1980 real income per capita rises from the 25 th percentile (\$730) to the 75 th $(\$ 5974)$ among the countries in the sample. The hypothesis of no interaction cannot be rejected. Moreover, the data appear inconsistent with the view that the effect declines substantially as real income rises. Even if the true coefficient on the interaction variable were two standard errors larger than the point estimate, the effect of openness and $\log$ average inflation would change only by 0.41 as real income rose from its 25 th percentile value to the 75 th percentile. ${ }^{26}$

Second, the importance of tariff revenue, and the strength of the link between country size and the use of tariffs, are much too small to account for the size of the link between openness and inflation. Because even very small countries obtain only moderate fractions of their revenues from tariffs, the use of tariffs does not free these countries from the need to obtain

16 Excluding the oil producers (for whom per capita income is a poor measure of development) changes these results only trivially. When the 18 highly developed countries are excluded, the coefficient on the interaction term increases to -0.72 and becomes significant. With regional dummies included, however, the coefficient remains negative but returns to being insignificant. 
significant revenues from other sources. Consider for example a regression of the fraction of central government revenue obtained from tariffs on a constant, openness, the dumny for the alternative measure of openness, and $\log$ real per capita income. ${ }^{17}$ The coefficient estimates from this regression imply that for a country with per capita income equal to the sample median, as the share of imports in GDP falls from 608 to 208, the fraction of the government's revenue coming from tariffs falls from 278 to 188; thus the fraction coming from sources other than tariffs rises by about 13\%. The basic openness-inflation regressions (for example, Column 3 of Table 1), however, imply that the same change in openness is associated with an increase of 508 in average inflation. It is simply not plausible that this very large increase in inflation could be the result simply of shifting away from tariffs toward all other revenue sources. This could occur only if seignorage revenues were only very slightly increasing in the inflation rate; as I describe below, this does not appear to be the case. Thus it appears that the tariff-based explanation can account for at most a small part of the opennessinflation relationship.

The third piece of evidence that the budget-based explanations of the results are not correct is that the elasticity of money demand also does not appear to vary in a quantitatively important way with the degree of openness. Fair (1987) and Driscoll and Lahiri (1983) estimate money demand functions for

17 Because of the obvious simultanelty problem -- increased reliance on tariffs reduces measured openness - the regression (like those in Table 3 ) is estimated by instrumental variables, treating openness as endogenous and employing $\log$ land area as an instrument. The data on tariff revenue are for 1980 and cover 97 of the 114 countries; they are from the IMF (1986b. PP. 2425). 
large groups of countries. ${ }^{18}$ Fair focuses on developed countries; his sample consists of twenty OECD members and six less developed countries. He estimates money demand with the interest rate entered both in logarithms and in levels; the dependent variable is the $\log$ of the real money stack in both cases. Driscoll and Lahiri consider twelve less developed countries. They use the inverse of velocity as their dependent variable and inflation (rather than the interest rate) as their measure of the cost of holding money, and inflation is entered linearly.

Table 4 presents simple regressions of these estimates of the interest or inflation sensitivity of money demand on the degree of openness. ${ }^{29}$ The results suggest a small and statistically insignificant effect of openness on the slope of the money demand function. All of the estimated coefficients are insignificant, and in one case the regression suggests that money demand is in fact less elastic in more open economies. In addition, both Fair's and Driscoll and Lahiri's estimates suggest that the elasticity of money demand is small (less than 0.1), even in quite open economies. ${ }^{20}$ Thus the possible loss of seignorage revenues is unlikely to be a central determinant of the average inflation rate in most situations: over the relevant range, higher inflation

18 The measure of money used by these authors is the sum of currency and demand deposits rather than high-powered money, which is what is relevant for seignorage. But the argument that the interest elasticity of the demand for high-powered money is higher in more open economies appears to apply equally well to the demand for currency and demand deposits.

19 Fair's estimates are from his Table 1; Driscoll and Lahiri's are from their Table 1. Adding the log of average inflation or the log of per capita income to the regressions has no important effect on the results.

20 To convert the fitted semi-elasticities in Column 2 into elasticities it is necessary to multiply by the interest rate; since Fair enters the interest rate in percent, for an interest rate of 15 the fitted values must be multiplied by 15 . For Column 3, the conversion factor is the product of velocity and the inflation rate. Thus for inflation of 158 and velocity equal to 5 , the fitted values must be multiplied by 75 . The resulting elasticities are consistently less than 0.1 . 
TABLE 4

THE RELATIONSHIP BETWEEN OPENNESS AND

THE ELASTICITY OF MONEY DEMAND

\begin{tabular}{lccc}
\hline & $(1)$ & $(2)$ & $(3)$ \\
\hline Interest Elasticity & $\begin{array}{c}\text { Interest } \\
\text { of Money Demand } \\
\text { (Fair, 1987) }\end{array}$ & $\begin{array}{c}\text { Semi-Elasticity } \\
\text { of Money Demand } \\
\text { (Fair, 1987) }\end{array}$ & $\begin{array}{c}\text { Inflation Sensitivity } \\
\text { of Inverse Velocity } \\
\text { (Driscoll and Lahri, 1983) }\end{array}$ \\
\hline Constant & -0.0364 & -0.00073 & -0.000031 \\
Openness & $(0.0153)$ & $(0.00190)$ & $(0.000758)$ \\
& 0.0150 & -0.00787 & -0.00161 \\
$\mathrm{R}^{2}$ & $(0.0488)$ & $(0.00606)$ & $(0.00283)$ \\
& .004 & .066 & .031 \\
S.E.E. & .032 & .0039 & .00097 \\
\hline
\end{tabular}


leads to little erosion of the money stock. ${ }^{21}$

In sum, both budgetary explanations of the link between openness and

inflation are contradicted by the fact that the link does not become weaker as

real income rises. In addition, the basic mechanisms underlying both

explanations appear much too weak to account for the magnitude of the

openness-inflation link: small countries obtain only moderately more revenues

from tariffs than large countries, and the elasticity of money demand is small

and is at most only slightly increasing in openness.

21 The evidence from hyperinflations (both historical and modern) also suggests small inflation or interest elasticities of money demand. Despite vast increases in inflation, real money holdings (and real high-powered money holdings) typically fall by much less than a factor of ten in hyperinflations. The estimates in Cagan's classic study, for example, imply that the long-run inflation elasticity of money demand is generally less than 0.1 for inflation rates less than 208, and that the inflation rate that maximizes steady state seignorage is typically not reached until inflation (measured as the change in the $\log$ of the price level) reaches about 3008 (Cagan, 1956). 
IV. CONCLUSION

This paper demonstrates that average rates of inflation are lower in more open economies. This relationship is statistically significant, quantitatively large, and robust. It holds over a wide range of countries, with the exception of a small group of highly developed countries in which average inflation rates are low and unrelated to openness. Finally, the relationship accounts for a moderate amount of the overall cross-country variation in average inflation rates.

The paper also proposes an explanation of this relationship. Because unanticipated monetary expansion causes real exchange rate depreciation, and because the harms of real depreciation are greater in more open economies, the benefits of surprise expansion are a decreasing function of the degree of openness. Thus if the monetary authorities' temptation to expand is an important determinant of inflation - that 1s, if the absence of binding precomitment is important to monetary policy - - monetary authorities in more open economies will on average. expand less, and the result will be lower average rates of inflation. This interpretation of the results implies that the most highly developed countries may have found some means of overcoming the problem of dynamic inconsistency of optimal monetary policy, but that the remaining countries of the world have not. The paper considers two other candidate explanations of the inverse relation between openness and inflation, one based on endogenous openness and one based on how governments' ability to collect different types of revenue varies with openness, and finds that neither fit the facts. 
These findings suggest that models in which the absence of precommitment In monetary policy leads to Inefficiently high average levels of inflation are essential to understanding inflation in most of the world. The results also suggest that increased economic cooperation and integration, particularly outside the most highly developed countries, should be viewed with caution: in the absence of some mechanism to overcome the dynamic inconsistency problem, increased integration may lead to large increases in average inflation. 


\section{REFERENCES}

Alesina, Alberto. 1988. "Macroeconomics and Politics." NBER Macroeconomics Annual 3: $13-52$.

Ball, Laurence, and Romer, David. 1990. "Real Rigidities and the NonNeutrality of Money." Review of Economic Studies 57 (April): 183-203.

Barro, Robert J., and Gordon, David B. 1983a. "A Positive Theory of Monetary Policy in a Natural Rate Model." Journal of Political Economy 91 (August): $589-610$.

Barro, Robert J., and Gordon, David B. 1983b. "Rules, Discretion and Reputation in a Model of Monetary Policy." Journal of Monetary Economics 12 (July): 101-121.

Blanchard, Olivier Jean, and Kiyotaki, Nobuhiro. 1987. "Monopolistic Competition and the Effects of Aggregate Demand." American Economic Revlew 77 (September): 647-666.

Cagan, Phillip. 1956. "The Monetary Dynamics of Hyperinflation." In Milton Friedman, ed., Studies in the Quantity Theory of Money (Chicago: University of Chicago Press, 25-117.

Cukierman, Alex, Edwards, Sebastian, and Tabellini, Guido. 1989. "Seignorage and Political Instability." Mimeo, UCLA.

Driscoll, Michael J., and Lahiri, Ashok K. 1983. "Income-Velocity of Money in Agricultural Developing Economies." Review of Economics and Statistics 65 (August): 393-401.

Fair, Ray C. 1987. "International Evidence on the Demand for Money." Review of Economics and Statistics 69 (August): $473-480$.

Fischer, Stanley. 1990. "Rules versus Discretion In Monetary Policy." In Benjamin M. Friedman and Frank H. Hahn, eds., Handbook of Monetary Economics (Amsterdam: North-Holland), vol. 2, 1155-1184.

International Monetary Fund. 1986a. International Financial Statistics Supplement on Price Statistics. IFS Supplement Series, no. 12.

International Monetary Fund. 1986b. International Financial Statistics Supplement on Government Finance. IFS Supplement Series, no. 11.

International Monetary Fund. 1988. International Financial Statistics Supplement on Trade Statistics. Supplement Series, no. 15.

Kydland, Finn E., and Prescott, Edward C. 1977. "Rules Rather than Discretion: The Inconsistency of Optimal Plans." Journal of Political Economy 85 (June): $473-492$. 
Phelps, Edmund S. 1967. "Phlllips Curves, Expectations of Inflation, and Optimal Employment over TIme." Economlca 34: 254-281.

Rogoff, Kenneth. 1985a. "The Optimal Degree of Commitment to an Intermediate Monetary Target." Quarterly Journal of Economics 100 (November): 1169 . 1190.

Rogoff, Kenneth. 1985b. "Can International Monetary Policy Cooperation Be Counterproductive?" Journal of International Economics 18: 199-217.

Rogoff, Kenneth. 1989. "Reputations, Coordination, and Monetary Pollcy." In Robert J. Barro, ed., Modern Business Cycle Theory (Cambridge: Harvard University Press), 236-264.

Sheffrin, Steven M. 1988. "Two Tests of Rational Partisan Business Cycle Theory." Mimeo, University of California, Davis.

Summers, Robert, and Heston, Alan, 1988. "A New Set of International Comparisons of Real Product and Price Levels Estimates for 130 Countries, 1950-1985. Review of Income and Weslth 34 (March): 1-25.

Taylor, John B. 1983. "Comments." Journal of Monetary Economics 12 (July): $123-125$. 
TABLE A1

BASIC DATA

\begin{tabular}{|c|c|c|c|c|}
\hline Country & $\begin{array}{l}\text { Average } \\
\text { Share of } \\
\text { Imports in } \\
\text { GDP } \\
\text { since } 1973\end{array}$ & $\begin{array}{c}\text { Average } \\
\text { Inflation } \\
\text { since } 1973 \\
\end{array}$ & $\begin{array}{l}1980 \text { Real } \\
\text { Income per } \\
\text { Capita, } \\
\text { U.S.S }\end{array}$ & $\begin{array}{l}\text { Land Area, } \\
\text { Square Miles }\end{array}$ \\
\hline Algeria & $31.4 \%$ & $9.9 \%$ & 1998 & 919595 \\
\hline Argentina $^{d}$ & 9.4 & 117.0 & 4342 & 1072067 \\
\hline Australiad & 16.7 & 9.5 & 8349 & 2966150 \\
\hline Austria ${ }^{d}$ & 35.6 & 5.0 & 8230 & 32375 \\
\hline Bahrain ${ }^{c}$ & 91.0 & 4.8 & 9185 & 240 \\
\hline Bangladesh $^{b}$ & 17.0 & 129 & 540 & 55598 \\
\hline Barbados $^{\star}$ & 72.8 & 10.7 & 4454 & 166 \\
\hline Belgium ${ }^{\star}$ & 58.8 & 6.0 & 9228 & 11781 \\
\hline Benin & 38.9 & 10.3 & 534 & 43483 \\
\hline Boliviad & 23.2 & 206.7 & 1529 & 424162 \\
\hline Botswana ${ }^{d}$ & 66.4 & 10.1 & 1477 & 231800 \\
\hline Brazil $^{d}$ & 7.4 & 74.1 & 3356 & 3286470 \\
\hline Burkina Faso ${ }^{a}$ & 40.7 & 8.8 & 358 & 105870 \\
\hline Burma & 8.9 & 5.5 & 483 & 261220 \\
\hline Burundi & 19.5 & 8.3 & 333 & 10747 \\
\hline Cameroon" & 24.3 & 10.2 & 875 & 183569 \\
\hline Canada $^{d}$ & 24.5 & 7.1 & 11332 & 3851809 \\
\hline Central Afr. Rep. & 13.9 & 10.7 & 487 & 241313 \\
\hline Chile $^{d}$ & 23.1 & 59.4 & 4271 & 292132 \\
\hline Colombia $^{d}$ & 13.7 & 21.6 & 2552 & 439735 \\
\hline Congo & 55.0 & 10.9 & 981 & 132046 \\
\hline Costa Rica & 37.8 & 20.6 & 3031 & 19652 \\
\hline Cyprus ${ }^{d}$ & 60.0 & 8.9 & 4282 & 3572 \\
\hline Denmark $^{\alpha}$ & 33.2 & 8.1 & 9598 & 16031 \\
\hline Dominican Republic ${ }^{d}$ & 21.4 & 12.1 & 1868 & 18704 \\
\hline Ecuador $^{d}$ & 25.0 & 20.4 & 2607 & 109484 \\
\hline Egypt ${ }^{a}$ & 32.9 & 8.9 & 995 & 386900 \\
\hline El Salvador & 33.4 & 13.1 & 1410 & 8260 \\
\hline Ethiopia & 18.1 & 4.4 & 325 & 472432 \\
\hline $\mathrm{Fiji}^{\mathrm{d}}$ & 49.1 & 9.5 & 3005 & 7078 \\
\hline Finland $^{d}$ & 28.6 & 9.4 & 8393 & 130119 \\
\hline France $^{d}$ & 21.1 & 8.9 & $\mathscr{Y 6 8 8}$ & 211208 \\
\hline Gabone,c & 34.3 & 13.3 & 2973 & 103346 \\
\hline Gambia $^{b}$ & 56.5 & 14.9 & 556 & 4093 \\
\hline Germany $^{d}$ & 26.6 & 3.8 & 9795 & 96010 \\
\hline Ghana & 13.1 & 38.2 & 421 & 92100 \\
\hline Greece $^{d}$ & 27.6 & 16.2 & 4383 & 50961 \\
\hline Guatemala $^{d}$ & 21.9 & 11.7 & 1952 & 42042 \\
\hline Guyana & 72.1 & 11.8 & 1623 & 83000 \\
\hline
\end{tabular}




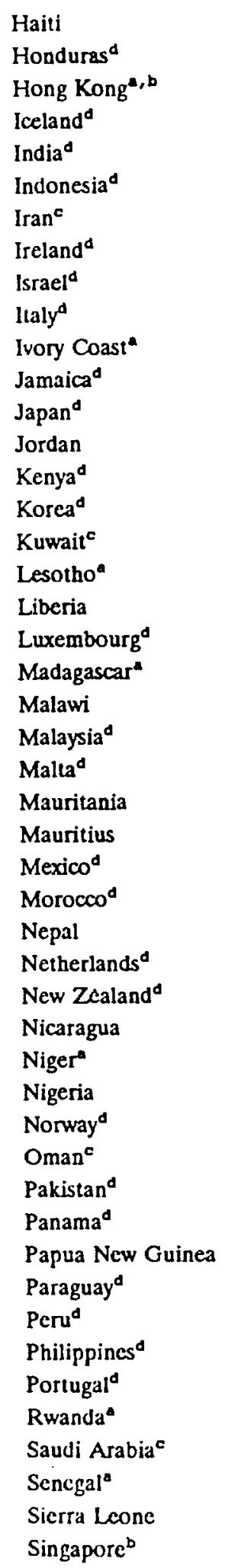

\begin{tabular}{|c|c|c|c|}
\hline 34.4 & 6.0 & 696 & 10714 \\
\hline 35.6 & 7.1 & 1075 & 43277 \\
\hline 81.7 & 8.3 & 7268 & 398 \\
\hline 39.3 & 35.1 & 9285 & 39709 \\
\hline 8.1 & 7.8 & 614 & 1229737 \\
\hline 21.8 & 14.5 & 1063 & 735268 \\
\hline 18.3 & 16.2 & 2944 & 636293 \\
\hline 56.6 & 11.1 & 4929 & 26600 \\
\hline 57.5 & 75.3 & 6145 & 8020 \\
\hline 22.9 & 13.8 & 7164 & 116500 \\
\hline 37.0 & 10.6 & 1110 & 124502 \\
\hline 49.3 & 16.8 & 1858 & 4411 \\
\hline 12.9 & 4.3 & 9447 & 143574 \\
\hline 94.6 & 7.9 & 1885 & 37297 \\
\hline 32.0 & 10.3 & 662 & 224960 \\
\hline 36.3 & 13.0 & 2369 & 38031 \\
\hline 38.3 & 9.6 & 19454 & 6880 \\
\hline 117.8 & 10.7 & 694 & 11720 \\
\hline 55.7 & 7.8 & 680 & 43000 \\
\hline 76.5 & 6.1 & 10173 & 999 \\
\hline 22.8 & 13.2 & 589 & 226660 \\
\hline 33.9 & 11.1 & 417 & 45747 \\
\hline 51.7 & 4.6 & 3112 & 128328 \\
\hline 91.6 & 4.2 & 4630 & 122 \\
\hline 66.7 & 9.9 & 576 & 397953 \\
\hline 57.1 & 13.3 & 1484 & 787 \\
\hline 10.8 & 32.8 & 4333 & 761600 \\
\hline 31.4 & 8.4 & 1199 & 172413 \\
\hline 18.6 & 9.0 & 490 & 54463 \\
\hline 50.7 & 4.6 & 9036 & 16041 \\
\hline 30.8 & 11.6 & 7363 & 103884 \\
\hline 31.9 & 41.5 & 2012 & 50180 \\
\hline 32.5 & 13.8 & 441 & 489206 \\
\hline 17.8 & 15.1 & 824 & 356700 \\
\hline 42.7 & 7.7 & 11094 & 125049 \\
\hline 41.7 & 10.4 & 6209 & 82030 \\
\hline 20.1 & 9.7 & 989 & 310400 \\
\hline 43.5 & 5.4 & 2810 & 29761 \\
\hline 49.4 & 7.1 & 1528 & 178704 \\
\hline 21.9 & 15.7 & 1979 & 157047 \\
\hline 20.4 & 49.5 & 2456 & 496222 \\
\hline 22.6 & 13.1 & 1551 & 115830 \\
\hline 38.5 & 18.7 & 3733 & 35550 \\
\hline 18.6 & 10.1 & 379 & 10169 \\
\hline 35.3 & 10.0 & 11101 & 865000 \\
\hline 45.4 & 10.6 & 744 & 75954 \\
\hline 26.0 & 20.1 & 512 & 27700 \\
\hline 163.8 & 3.6 & 5817 & 220 \\
\hline
\end{tabular}




\begin{tabular}{|c|c|c|c|c|}
\hline Somalia ${ }^{a, b}$ & 18.4 & 26.9 & 415 & 246199 \\
\hline South Africa ${ }^{d}$ & 25.5 & 12.9 & 4286 & 471440 \\
\hline Spain ${ }^{d}$ & 18.3 & 13.7 & 6131 & 194885 \\
\hline Sri Lankad & 38.3 & 12.4 & 1119 & 25332 \\
\hline Sudan* & 15.8 & 21.2 & 652 & 967491 \\
\hline Surinam & 57.6 & 9.4 & 3760 & 63251 \\
\hline Swaziland & 77.9 & 13.6 & 1079 & 6704 \\
\hline Sweden ${ }^{d}$ & 30.4 & 8.9 & 8863 & 173800 \\
\hline Switzerland ${ }^{d}$ & 34.7 & 3.8 & 10013 & 15941 \\
\hline Syria ${ }^{d}$ & 29.8 & 13.5 & 3071 & 71498 \\
\hline Taiwand & 45.8 & 6.7 & 2921 & 13895 \\
\hline Tanzania $^{d}$ & 23.5 & 15.9 & 353 & 364900 \\
\hline Thailand $^{d}$ & 25.9 & 6.0 & 1694 & 198455 \\
\hline Togo & 49.0 & 8.9 & 625 & 21925 \\
\hline Trinidad \& Tobago ${ }^{d}$ & 37.1 & 14.2 & 7161 & 1980 \\
\hline Tunisia ${ }^{d}$ & 40.4 & 8.2 & 1845 & 63379 \\
\hline Turkey & 12.8 & 32.2 & 2319 & 300947 \\
\hline Ugandab $^{b}$ & 9.2 & 39.8 & 257 & 91343 \\
\hline U.A. Emirates ${ }^{c}$ & 33.2 & 10.2 & 25646 & 32000 \\
\hline United Kingdom ${ }^{d}$ & 27.2 & 10.6 & 7975 & 94247 \\
\hline United States $^{d}$ & 9.3 & 6.2 & 11404 & 3540939 \\
\hline Uruguay & 19.3 & 44.0 & 4502 & 68040 \\
\hline Venezuela & 24.3 & 14.0 & 4424 & 352143 \\
\hline Yemen & 46.7 & 13.0 & 957 & 128560 \\
\hline Zaire $^{a}$ & 39.6 & 43.2 & 224 & 905365 \\
\hline Zambia & 39.6 & 17.5 & 716 & 290586 \\
\hline Zimbabwe $^{\mathfrak{d}}$ & 27.7 & 10.4 & 930 & 150699 \\
\hline
\end{tabular}

- Inflation computed using CPI data.

b Import share data from IMF (1988).

c. Major oil producer.

“ In "good data" sample. 